Acta vet. scand. $1968,9,302-307$.

From the State Veterinary Medical Institute, Helsinki, Finland.

\title{
THE INFLUENCE OF MASTITIS, LOCAL PERITONITIS AND DISTOMATOSIS ON THE LYMPHOCYTIC PICTURE OF BOVINE BLOOD
}

\author{
By \\ O. Sorvettula and P. Andersson
}

In the eradication of bovine adult leukosis, various hematological methods are widely in use. The aim is to detect the early preclinical cases. The results are interpreted with the help of various leukosis keys. Stöber (1965) and Wiesner (1967) have reviewed the subject very thoroughly. The hematological methods have, however, a serious shortcoming. They are not specific enough, which creates problems in diagnostic work. To avoid false conclusions, several chronic diseases are worth noting in connection with blood sampling, because even longprevailing lymphocytosis has been observed in herds known to be free from leukosis. Studies on non-specific lymphocytosis have mainly been undertaken in herds with leukosis, with resultant difficulties in interpretation. Considerably less work has been done in herds free from leukosis.

Nieland (1930), as well as many others, have observed that tuberculotic mastitis can lead to a long-lasting lymphocytosis. Schöttler \& Schöttler (1934) refer to earlier works (Schwanitz 1920 and Knoblauch 1924) pointing out the importance of tuberculosis in this sense. In the opinion of Niepage (1953), hematological findings are not specific unless lymphocytes with certain morphological changes are found. This because he has found non-specific lymphocytosis in connection with the amputation of claws, local peritonitis, bovine malignant catarrh and retentio secundinarum. Götze et al. (1953) studied the material of a clinic to see whether diseases might create problems in the 
early diagnosis of leukosis. In their material, four cattle with piroplasmosis had a long-prevailing lymphocytosis. Nordström \& Otterlin (1957) have observed lymphocytosis in cases of mastitis, foreign body peritonitis, pneumonia, abscess and metritis. Niepage (1961) has seen lymphocytosis in clinically healthy as well as in chronically diseased cattle. According to him, cattle with distomatosis generally had low lymphocyte counts.

The purpose of this paper is to present the results of hematological, patho-anatomical and parasitological studies with the aim of seeing if cattle suffering from mastitis, local peritonitis or distomatosis show changes in the lymphocytic blood picture.

\section{MATERIAL AND METHODS}

In order to secure suitable material, a certain limited area was selected. Blood samples were collected from every animal from this area coming to the slaughterhouse. During the subsequent meat inspection a careful examination was performed with special attention to disease conditions which might possibly change the blood picture. All findings were recorded and samples were taken for histological examination when needed. In this way, 232 suitable samples were collected. EDTA* was used as the anticoagulant and the hematological tests were performed within 24 hrs. Samples were hemolyzed with saponine and in each the white cells were counted twice using a Celloscope 202 electronic computer. Blood films were stained with MacNeal's tetrachrome stain ${ }^{\star *}$, and differential counting of 100 white cells was done. Histological slides were prepared of udders and livers, using routine methods. The results were finally processed on an electronic computer (Student's t-test).

\section{RESULTS AND DISCUSSION}

The results are presented in Tables 1 to 3 . The animals are divided into four age groups. There were a few animals with more than one of the above-mentioned diseases. One had all three conditions, 7 had mastitis and distomatosis, 8 peritonitis and distomatosis, and 3 mastitis and peritonitis simultaneously.

* Manufactured by E. Merck AG, Darmstadt, W. Germany.

* Manufactured by Hopkin \& Williams Ltd, Chadwell Heath, England. 
Five cases of mastitis were histologically considered acute and 10 chronic.

Key to the tables

\begin{tabular}{|lll|}
\hline & A & \\
B & & D \\
C & & E \\
\hline
\end{tabular}
A - number of animals
$B$ - average of the total number of leukocytes $/ \mathrm{mm}^{3}$
C - standard deviation of $B$
D - average of the \% of lympho- cytes
$\mathrm{E}$ - standard deviation of $\mathrm{D}$

T a b l e 1. The total number of leukocytes and percentage of lymphocytes in bovines with distomatosis as compared with the rest of the experimental group.

\begin{tabular}{|c|c|c|c|c|c|c|}
\hline \multirow{4}{*}{$\frac{\begin{array}{c}\text { Age in } \\
\text { years }\end{array}}{1 \mathrm{yr} .}$} & \multicolumn{2}{|c|}{ No distomatosis } & \multicolumn{2}{|c|}{ Mild distomatosis } & \multicolumn{2}{|c|}{ Severe distomatosis } \\
\hline & \multicolumn{2}{|c|}{64} & \multicolumn{2}{|c|}{13} & \multicolumn{2}{|c|}{3} \\
\hline & 6108 & 56.61 & 6592 & 56.62 & 4600 & 61.33 \\
\hline & 1979 & 12.88 & 1950 & 15.76 & 1296 & 6.18 \\
\hline \multirow[t]{3}{*}{2 yrs. } & \multicolumn{2}{|c|}{14} & \multicolumn{2}{|c|}{3} & \multicolumn{2}{|c|}{3} \\
\hline & 5521 & 52.64 & 5700 & 58.00 & 4767 & 54.33 \\
\hline & 1875 & 13.53 & 942 & 11.43 & 946 & 12.66 \\
\hline \multirow[t]{3}{*}{3 yrs. } & \multicolumn{2}{|c|}{9} & \multicolumn{2}{|c|}{2} & \multicolumn{2}{|c|}{1} \\
\hline & 5089 & 55.00 & 5350 & 37.50 & 4500 & 49.00 \\
\hline & 1901 & 13.16 & 1850 & 12.50 & - & - \\
\hline 4 or & \multicolumn{2}{|c|}{56} & \multicolumn{2}{|c|}{31} & \multicolumn{2}{|c|}{33} \\
\hline more & 4402 & 53.13 & 4781 & 54.00 & 4312 & 49.88 \\
\hline yrs. & 1627 & 11.26 & 1658 & 12.53 & 952 & 8.95 \\
\hline
\end{tabular}

There is no significant difference within the age groups between distomatotic and non-distomatotic populations. Neither is there any significant difference in the percentage of lymphocytes, and thus no significant difference in the total number.

Although animals under 4 years of age suffering from distomatosis are under-represented, with perhaps the one exception of yearlings with mild distomatosis, it can be observed that there are no indications that significant differences could be expected between distomatotic and non-distomatotic groups.

The only age group where a comparison of results between the populations is possible is the last one, 4 years and older; in 
T a ble 2. The total number of leukocytes and percentage of lymphocytes in bovines with mastitis as compared with the rest of the experimental group.

\begin{tabular}{|c|c|c|c|c|}
\hline \multirow{4}{*}{$\begin{array}{l}\begin{array}{c}\text { Age in } \\
\text { years }\end{array} \\
1 \mathrm{yr} .\end{array}$} & \multicolumn{2}{|c|}{ No mastitis } & \multicolumn{2}{|c|}{ Mastitis } \\
\hline & \multicolumn{2}{|c|}{80} & \multicolumn{2}{|c|}{-} \\
\hline & 6130 & 56.79 & & \\
\hline & 1840 & 13.24 & & \\
\hline \multirow[t]{3}{*}{2 yrs. } & \multicolumn{2}{|c|}{19} & \multicolumn{2}{|c|}{1} \\
\hline & 5521 & 53.89 & 3800 & 50.00 \\
\hline & 1676 & 13.56 & - & - \\
\hline \multirow[t]{3}{*}{3 yrs. } & \multicolumn{2}{|c|}{12} & \multicolumn{2}{|c|}{ - } \\
\hline & 5083 & 51.58 & & \\
\hline & 1822 & 14.08 & & \\
\hline 4 or & \multicolumn{2}{|c|}{106} & \multicolumn{2}{|c|}{14} \\
\hline more & 4377 & 51.94 & 4329 & 56.36 \\
\hline yrs. & 1474 & 10.66 & 1542 & 13.74 \\
\hline
\end{tabular}

this age group there is no significant difference, neither in the total number nor in the percentage of lymphocytes. In the younger age groups, comparison was impossible because mastitis cases were too scarce.

T a b l e 3. The total number of leucocytes and percentage of lymphocytes in bovines with local peritonitis as compared with the rest of the experimental group.

\begin{tabular}{|c|c|c|c|c|}
\hline \multirow{3}{*}{$\frac{\begin{array}{c}\text { Age in } \\
\text { years }\end{array}}{1 \mathrm{yr} .}$} & \multicolumn{2}{|c|}{ No peritonitis } & \multicolumn{2}{|c|}{ Peritonitis } \\
\hline & \multicolumn{2}{|c|}{79} & \multicolumn{2}{|c|}{1} \\
\hline & 6142 & 56.80 & 5200 & 56.00 \\
\hline & 1849 & 13.32 & - & - \\
\hline \multirow[t]{3}{*}{2 yrs. } & \multicolumn{2}{|c|}{20} & \multicolumn{2}{|c|}{ - } \\
\hline & 5435 & 53.70 & & \\
\hline & 1676 & 13.24 & & \\
\hline \multirow[t]{3}{*}{3 yrs. } & \multicolumn{2}{|c|}{9} & \multicolumn{2}{|c|}{3} \\
\hline & 5167 & 49.22 & 4833 & 58.67 \\
\hline & 1509 & 14.57 & 2522 & 9.46 \\
\hline 4 or & \multicolumn{2}{|c|}{101} & \multicolumn{2}{|c|}{19} \\
\hline more & 4317 & 52.41 & 4663 & 52.74 \\
\hline yrs. & 1395 & 10.99 & 1850 & 11.99 \\
\hline
\end{tabular}


In those groups where statistical analysis is possible there are no significant differences between the groups.

In this material, distomatosis, mastitis and local peritonitis have thus resulted in no significant changes neither in the total number nor in the percentage of lymphocytes. It is interesting to note that animals suffering from distomatosis generally had low values, though significant differences could not be detected. Niepage (1961) has made a somewhat similar observation.

\section{REFERENCES}

Götze, R., G. Ziegenhagen \& H. Merkt: Zur Diagnose der Leukose des Rindes. Mh. Tierheilk. 1953, 5, 201-211.

Knoblauch, C.: Über die Veränderungen der weissen Blutzellen des Rindes und des Hundes unter den Einfluss verschiedener Infektions- und Invasionskrankheiten. Diss. Berlin 1924.

Nieland, H.: Ein Beitrag zur Diagnose des Frühstadiums der Eutertuberkulose. Diss. Berlin 1930.

Niepage, H.: Der gegenwärtige Stand der Leukoseforschung beim Rinde. Mh. Vet.-Med. 1953, 8, 396-398.

Niepage, H.: Untersuchungen über das Differentialblutbild des Rindes. Zbl. Vet.-Med. 1961, 8, 282-301, 305-322.

Nordström, G. \& S. E. Otterlin: Lymphatic leukaemia in cattle - a study of the value of the blood picture in diagnosis. Acta agric. scand. 1957, 7, 298-310.

Schöttler, F. \& H. Schöttler: Über die Ätiologie und Therapie der aleukämischen Lymphadenose des Rindes. Berl. tierärztl. Wschr. 1934, 50, 497-502, 513-517.

Schwanitz, A.: Das Blutbild des Rindes bei Tuberkulose, Lungenseuche und septischen Erkrankungen. Diss. Berlin 1920.

Stöber, M.: Zytomorphologische und zytochemische Blutuntersuchungen beim Rind im Hinblick auf ihre Brauchbarkeit für die Diagnose der lymphatischen Leukose. Diss. Hannover 1965.

Wiesner, E.: Die Leukosen des Rindes. 2nd Ed. Verlag G. Fischer, Jena 1967.

\section{SUMMARY}

The authors have studied hematologically and patho-anatomically 232 slaughter cattle, of which 89 had distomatosis, 15 mastitis and 23 local peritonitis. None was observed to have lymphocytosis. The statistical comparison between the age groups and between diseased and healthy animals did not reveal any significant differences in the total count of leukocytes or in the relative number of lymphocytes. 


\section{ZUSAMMENFASSUNG}

Der Effekt von Euterentzündungen, lokalen Bauchfellentzündungen und Distomatose auf dem Lymphozytenbild des Rinderblutes.

Die Verfasser haben 232 Schlachtrinder hämatologisch und patologanatomisch untersucht. 89 von den Tieren litten an Distomatose, 15 an Euterentzündung und 23 an lokaler Bauchfellentzündung. Kein Tier hatte Lymphozytose. Ein statistischer Vergleich ergab keine signifikante Differenzen zwischen den verschiedenen Gruppen weder in der totalen Anzahl der Leukozyten noch in der relativen Zahl der Lymphozyten.

\section{SAMMANFATTNING}

Effekten av mastiter, lokala peritoniter och distomatos på nötkreaturens blodlymfocytbild.

Författarna har hematologiskt och patoanatomiskt undersökt 232 slaktnöt, av vilka 89 led av distomatos, 15 av mastit och 23 av lokal peritonit. Inget djur visade lymfocytos. Statistisk jämförelse av de olika åldersgrupperna och av de olika sjukdomsgrupperna gav inga signifikanta skillnader varken $i$ det totala leukocytantalet eller det procentuella lymfocytvärdet.

(Received May 8, 1968). 